NORDISK MUSEOLOGI $1998 \cdot 1$, S. 9-16

\title{
WHAT I THINK OF AS MY HERITAGE
}

\section{Kenneth Hudson}

A few years ago I was in Richmond, Virginia, and while I was there I paid a visit to the Virginia Museum of Fine Arts. One department contained a collection of paintings devoted to sporting subjects. This had been given to the Museum by a rich man who had brought it together over a period of more than 30 years. The pictures were mainly from the 18th and 19th centuries and a high proportion of the artists were British. There was a particularly fine series of works by George Stubbs.

As soon as I realised what I was looking at, I began to boil with rage, although I managed to conceal this from my very kind host. What so incensed me was the fact that pictures which I regarded as part of my heritage had been bought by an American and transported bound and helpless across the Atlantic to a place which did not deserve to have them, a museum where they did not belong. My reaction was purely emotional and instinctive. Stubbs was there and I felt that he had been stolen from me.

The experience marked an important stage in my personal development, in my education, if you like. It forced me to think much more carefully about the nature of my cultural inheritance and indeed about the ingredients of my personal culture, if I dare use this vague and unhelpful word. I have come to the following conclusions and I am prepared to defend them on this or any other occasion. I have two forms of cultural inheritance or 'heritage'. to use today's fashionable word. The first consists of what has come down to me through my family, my inherited personal characteristics, the influence of my upbringing and certain physical possessions, a few books and items of furniture. Those represent my private heritage. My public heritage comprises anything which was built, written, painted, created or composed in Britain. So the Stubbs paintings in Richmond, Virginia, are part of my heritage, not the Virginian or American heritage.

I make a clear distinction between heritage and culture. Because I am British, Shakespeare is part of my heritage and my culture, but Mozart is only part of my cul- 
ture. If I were Austrian, he would be part of my heritage as well. Put in a different way I would fight to death to prevent a painting by Stubbs or Stanley Spencer from being exported, but I would shed no tears if a Cezanne were to be sold to a Japanese collector by its British owner. If I were French, I hope and believe I would feel differently. I believe it is politically incorrect these days to think of oneself as British, German, Turkish or to have any other national allegiance, but I feel no need to apologise for feeling British, rather than as a citizen of the world, with no roots in the country where I was born and brought up. All my life I have been surrounded by English buildings and the English countryside, I have had to respect English laws, customs and institutions, I have had an English education, English is my first language, I have earned most of my living in England and my pensions are paid in England in English money. How could I reasonably think about other countries in the same way as I think about England? The graves in which generations of my family are buried are part of my heritage and they are in England, not in Pakistan or the West Indies.

\section{ALBRECHT DURER AND CAMBRIDGE}

As I write this I notice in the newspaper that a painting by Albrecht Dürer, which has been on indefinite loan to the Fitzwilliam Museum in Cambridge, is to be sold by its private owner unless the Museum can raise $£ 10$ million, the picture's estimated saleroom value. Members of the public are asked to make contributions towards the purchase price, in order to 'save this masterpiece for the nation'. I myself do not propose to do so, and I should like to explain why. First and foremost because Dürer was not a British artist. This particular painting has been in England for a very long time, long enough, in the opinion of many people, to qualify for British citizenship. This is rather like saying that, because Handel spent so many years in England and was so much at home here, he was in effect an English composer. But long residence abroad, whether by a picture or by a person, does not automatically make something or somebody part of the national heritage. What we have and hold is not necessarily part of our heritage.

The problem is a difficult one, because it involves the difference between private and public property. Let us take the case of a wealthy titled family which built a large house in the 17 th or 18 th century and then stocked it, generation after generation, with valuable furniture and works of art. Let us assume that the property passed from father to son over a long period, so that objects acquired in, say, the 18 th century and made, some in England, some abroad, were in the possession of the same family 200 years later. The present head of the family could then claim, very reasonably, that both the property and the title constituted his heritage. He had a legal title to these things. They were his.

But I should not, could not consider that they formed part of my heritage. Would I have any different attitude to them if his house, or parts of it, were regularly open to the public, so that I was free to walk around and look at these precious objects? Or if, as one of his friends, I often visited the house and was as familiar 
with its contents as I was with my own possessions? Let us further suppose that the family died out or, for whatever reason, decided to sell the house and dispose of what was in it or give both or either to the National Trust or a museum, so that they became public property. Would I then regard what had been the Duke of Winchester's heritage as my heritage? Does something have to be public property before it can be regarded as part of the national heritage? Or is a private owner to be considered to be holding and looking after his belongings temporarily on behalf of the nation, which will acquire them eventually?

I have always imagined that Russians must have been very confused about such questions immediately after the Revolution, when the property of wealthy families was automatically taken over by the State. Was there a feeling that 'all this belongs to us now', or was the State as remote from them as the previous owners had been, so that the Revolution really made very little difference to the way in which they thought about their 'heritage', if indeed the majority of people even thought about such matters at all, either before or after the Revolution.

There is, however, a philosophical problem of some importance here. One can hardly deny that the Duke of Winchester would regard both the title and the property left to him by his father as his heritage, irrespective of what the property may have consisted of. He was most unlikely to have said or believed that the two family portraits by Gainsborough hanging in the drawing-room were part of his heritage, because they had been created by an English painter, whereas the Canalettos in the dining-room were not, since Canaletto was an Italian. Why, then, should one regard them any differently if and when they were public property? But to me there is a significant difference. The Duke of Winchester saw his Canalettos and his Gainsboroughs in the same way, because his links with them were via his father and his family, not with the artists, whereas the only bridge which exists for me is directly between the picture and the artist and myself. The bridge is partly intellectual and partly emotional and what I am trying to say is that the emotional components of the bridge are stronger if the artist shared my national culture. Gainsborough has an extra something which Canaletto does not have and that extra something constitutes what is, for me, his heritage value.

This has nothing to do with the artistic merit of the works in question. Heritage, as far as I am concerned, is not determined by intrinsic quality, but by roots and assocations and by a sense of belonging. Until four or five years ago I never thought that heritage could consist of portable objects. If someone had asked me what my heritage was, which in those days nobody ever did, I should probably have answered that it was the English language, the physical appearance of English towns and the English countryside and a set of attitudes not commonly found in other countries. In combination, these three things made me what I am, which is much the same as saying that a person's heritage consisted of lines stretching out behind him in the past. But these lines only exist if one is conscious of them. 
THE CONCEPT OF HERITAGE - IN ENGLISH

I have often thought in recent years that society, in the English-speaking world, would benefit a great deal if the use of the word 'heritage' could be banned for four or five years, since it is a word which prevents and confuses thought. Earlier this year I was invited once again to The Museums and Heritage Show in London. It is a big affair, lasting for two days and, not surprisingly, it is organised by The Museums and Heritage Show Limited. The programme included four seminars, two of which were of little interest to me, 'To Internet or Not' and 'It was US! Could it be you?', about funding from the National Lottery, but I looked more closely at the details of 'Heritage Retailing for the 21st Century' and 'The Architecture of Our Heritage'. The promotional material of the first of these began with the following inspirational paragraph. 'Retail trading', it said, 'provides a crucial source of revenue for most visitor attractions. This seminar is a must for anyone involved in retailing, aiming to present the latest trends, and offering a look into the future and what it holds in store for you'. The other seminar which dealt with 'The Architecture of our Heritage', provided guidance on 'How to draw together the artefacts representing our past in a way that is sensitive to an ever-changing social and physical environment'.

By this time, the message had become clear to me. There was a valuable commercial property called 'The Heritage' and there was a lot of money to be made from organising and presenting it in a businesslike fashion. In England we have been tal- king for several years about the Heritage Industry. My heritage, your heritage and the national heritage no longer exist in their own right. The Heritage Industry has taken command of the field and is determined to squeeze every milligram of profit out of the enterprise.

In the process, the word 'heritage' has been grossly debased and corrupted, which is why I do everything possible to avoid using the word. To those whose one aim is to make money, numbers are allimportant and, once it had become clear that there were impressive profits to be derived from what had survived from the past, the skill lay in organising and presenting bits and pieces of it in a way that would extract the maximum number of pounds, marks, francs or lire from the pockets of the public. The development is quite recent. As late as 1979, one of the most used and most reliable English dictionaries defined 'heritage' in two ways. It was 'something inherited at birth, such as personal characteristics and possessions', and it was also 'anything that has been transmitted from the past or handed down by tradition'. In whichever sense one used the word, it was never spelt with a capital letter and never as an absolute. It had to be qualified in some way, so that 'The Duke of Winchester's heritage' was correct and so was 'Kenneth Hudson's heritage' and 'the British heritage'. What was not possible at this date was an all-consuming monster known as 'The Heritage', with capital letters. It is the capital letter which is at the root of the problem. In today's salesman-controlled world, one should always be on one's guard when one meets a word spelt with a capital letter. It indicates an intention to weaken or 
destroy one's critical faculties, by suggesting that the person using the word is an authority and that there is no point in arguing with him.

\section{- IN GERMAN}

The same problem does not exist in German, where nouns always begin with a capital letter and for this reason always appear more important than the verb or verbs in the same sentence. This fact gives rise to further complications, because a noun indicates that an action has been completed and a decision arrived at, whereas the verb is evidence of continuing movement and progress. To give prominence to the noun is to condition a reader, if not a listener, to believe that argument and the search for alternative possibilities is at an end.

The English language is certainly impoverished by the modern use of Heritage, with or without the capital letter, as an absolute, but for the German language and for those who use it there is a different kind of complication. According to its context, 'heritage' can be translated into German by either 'Erbe' or 'Erbschaft'. The National Socialist use of both words combined the biological concept of inheritance, that is, inherited qualities, with the legal one of heritage.

In this way, pride of race and pride in landed property blended and supported one another. There was therefore not only the theory and the slogan of 'Blut und Erde', but also 'Blut und Erbe'. These associations have not entirely disappeared, and the words need to be used with a certain wariness today. The same is true of 'Heimatmuseum', a museum of the place where one lives, which still retains something of the overtones given to it by the Nazis.

\section{- IN FRENCH}

In France and the other Latin languages, the situation is different again. The French language has two words, 'héritage', the legal term for what a person inherits, and 'patrimoine', which referes, generally speaking, to survivals from the national past. But the two words are frequently confused and it is perfectly possible for someone to speak of his 'patrimoine', when he is thinking of the house and garden which he has inherited from his parents and which he in turn hopes to hand down to one or more of his children. The basic reason for this overlap of meaning is the side-by-side presence in the French mind of 'patrie', the Fatherland, and 'pater', a father, resulting from generations of adherence to the Catholic faith. The principal difference between what one might call heritage psychology in France and England is that in France 'le patrimoine' and everything it includes is reckoned to be in the overall care of the State, but in England 'the Heritage' has become increasingly an object of commercial attention and investment.

I think I can fairly claim to be as devoted to my national past as anyone in England, but I demand to be left alone to discover it, study it and enjoy it. My 'heritage' is essentially vague and its attraction lies in precisely that quality. It includes old buildings of all kinds, stretches of countryside, the people represented by the pictures of them in the National Portrait Gallery - my favourite museum - books 
14 and manuscripts by British authors, historic sites, music by English composers, costumes and a limitless range of practical objects, from cups and saucers to woodworking tools and from children's toys to royal tombs. 'Heritage', with a capital letter, implies organisation and selection and it also implies that it exists in order to provide an income for its impresarios. 'Heritage' , in other words, is processed 'heritage', graded, inspected, packaged, guaranteed and served up in a convenient form for the consumer. Once 'heritage' becomes 'Heritage' it loses its attractions for me. I want the raw materials of history in order to prepare my own meals.

In saying this, I understand very well that I am faced with a dilemma. If historical objects are not preserved, neither 'the Heritage', nor what I regard as my heritage can exist. And, since all forms of preservation cost money, where is the money to come from? During the past 20 years it has become perfectly clear in every country of Europe that public funds alone are inadequate if 'the heritage', however defined, is to be even tolerably well looked after. This is as true of cathedrals as it is of museum collections. If the job is to be done not only well, but at all, some form of direct contribution by the people who enjoy these things is inevitable. This in turn means, for each item or group of items in the public heritage, that people have to be persuaded that a visit would be worth their time and their money. And this means professional, that is, commercial organisation and presentation, so that if 'the heritage' is to survive it has to become 'the Heritage'. That, it would appear, is the price that has to be paid.

But the logic is seriously faulty in several important respects. The first is the failure to accept the fact that preservation is, quite inevitably, a highly selective process. Even under ideal circumstances, only a small part of 'the heritage' can possibly be properly cared for. The rest has to take its chance, as it has always done. The second breakdown in what we might call 'Heritage logic' is that there is a limit to what the public can be persuaded to visit. People cannot be on holiday all the time and, for reasons of both time and money, they have to ration their leisure activities. If they go to Place $A$, they cannot go to Place $B$, and if Place $C$ has a louder promotional voice than either Place $A$ or Place $\mathrm{B}$, they will go to Place $\mathrm{C}$. This is what The Museums and Heritage Show is really about - how to make the public come to your museum, your Heritage site, and not to those of your competitors'. The Heritage has become a ferocious battle, in which there are inevitably casualties.

The third failure of logic in the Heritage case, or at least in The Museums and Heritage Show case, is the apparent belief that looking after the Heritage is an essentially professional activity and that, efficiently organised, it can provide thousands of jobs. I am convinced that this is an illusion. Quite obviously, major tourist attractions like St Paul's Cathedral in London, can be maintained only by professionals. Repairing and restoring buildings of this size and quality is not a business for amateurs and volunteers. Equally, if the building is not in good order and structurally safe, nobody, either those attending services, or visitors, will be able to use it. So, because St Paul's is an important structure and because it is in daily 
use, it will somehow be looked after. The money will be found from somewhere. There are perhaps a hundred buildings in Britain which have this degree of priority. That part of the national heritage can be considered safe, at least for the time being. The real heritage, and therefore Heritage, problem concerns the thousands of later sites which demand great ingenuity, if they are to be preserved for tourists to look at. One has to assume, of course, that tourists deserve some benefit from looking at them, but this is uncertain and not for discussion at the moment. Just what intellectual or spiritual benefit a group of Japanese tourists obtains from a visit, guided or not, to Westminster Abbey, the Tower of London or, for that matter, the Acropolis is not clear to me. But they pay and one can only hope that they feel that they are getting value for money.

Our heritage/Heritage is not, however, only or mainly concerned with items like St Paul's Cathedral, the Partenon, the Roman Baths in Bath, or Shakespeare's Birthplace. Most of the huge collections of less prestigious places, from railway stations to port warehouses and from abandoned fishermen's cottages to old farm buildings and early lighthouses, are going to need a great deal of unpaid amateur effort if they are to be saved from decay and demolition. If I have a message to offer you today, it is that the bulk of the heritage in any country has to be looked after by people who demand no financial reward for what they do. My own heritage, and that of most other people, falls into two parts. Part One is my private heritage, those objects, documents and photographs, which belong to me personally and for the welfare of which I am directly responsible, and Part Two consists of my public heritage, those museum collections and on-site survivals which link me to British history and traditions and help me to understand them better. My Part Two heritage contains a great many items of which I have no personal knowledge but which I know would stir my imagination and feed my folk memory, if I was to see them. Meanwhile, I am grateful to those people who look after them on my behalf and hold them in readiness for a visit from me in the future. I try to do the same for them.

\section{THE IRONBRIDGE CASE}

I should like to end by telling you a story which seems to me to encapsulate both the follies and the grandeurs of the heritage fashion, heritage movement, or whatever you may like to call it. In the early 1960 s I was taken by a knowledgeable friend, Michael Rix, to Ironbridge, to look at one or two local things which, knowing of my pioneering interest in industrial archæology, he thought might interest me. There were four sites in particular, the Iron Bridge itself; the recently excavated remains of Abraham Darby's furnace in which iron was first smelted with coke; what had survived of a canal boat-lift; and a group of derelict furnaces at Blist's Hill, above the Avon Gorge. This, I ought to explain, was some years before the celebrated Ironbridge Gorge Museum was established and these historic monuments were peacefully decaying, as they had been for the past 200 years. To someone like myself who knew something of the industrial history of the area, they were immensely evocative, and they allo- 
16 wed me to imagine them as they were in their working days, when they formed part of one of the most important ironmaking complexes in the world.

If these scattered sites had been conserved more or less as they were or, as the Americans so beautifully put it, 'maintained in a state of arrested decay', they could have easily been made more accessible to interested people on payment of a small fee, interpreted in a basic way, and added to the national stock of industrial monuments. All that would have been needed at each of the four places would have been brief interpretations, a man or woman, probably a volunteer, to issue tickets, sell postcards and answer questions. The whole enterprise could have stayed small, with minimal overheads, and everybody who went there could have experienced the same feelings of wonder and discovery that had been aroused in me. The poetry of these remarkable monuments would have established direct communication with the self-selected people who had come to see them. There would have been no need to explain the meaning of 'industrial heritage'.

What actually happened was very different. An energetic and ambitious curator decided to turn the whole Gorge into a major, fully interpreted site. A well-funded Trust organisation was set up, a number of relevant buildings were acquired, restored and opened to the public and museums, a library and archive and a research institute created. A large staff was employed and Blist's Hill was turned into an extensive open-air museum, with dozens of buildings brought to the site from elsewhere. The consequence was, of course, that tens of thousands and, if pos- sible, hundreds of thousands of visitors were required, in order to get value from the investment, and sales and public relations organisations established in order to persuade sufficient numbers of people to come. What had been part of my heritage became within a few years part of Our Heritage and once that had happened I no longer wanted to go there. But Our Heritage is a greedy beast and in recent years it has been difficult to feed it. The number of visitors has seriously declined, income has fallen and staff have had to go. The moral is, I think, fairly obvious.

This paper was presented at the Department of Museology, Umeå university, in June 1996.

Kenneth Hudson is Director of The European Museum Forum. He is portrayed in Nordisk Museologi 1996/1, p. 126.

Adr PO Box 913, Bristol BS99 5 ST England

Fax +44-1179732437 